УДК [930.1+930.25] Флоровський

DOI: https://doi.org/10.33782/eminak2019.2(26).304

\title{
НЕОПУБЛІКОВАНИЙ НАРИС А.В. ФЛОРОВСЬКОГО «ПРО КАТЕРИНУ ІІ»: РЕКОНСТРУКЦІЯ НАУКОВОГО ДОРОБКУ
}

\author{
Анатолій Мирончук \\ Національна бібліотека України імені В.І. Вернадського (Київ, Україна) \\ e-mail: myronchuk@meta.ua \\ ORCID: https://orcid.org/0000-0001-5633-1413
}

У статті аналізується неопублікований нарис А.В. Флоровського «Про Катерину ІІ» $з$ його особового фонду в Архіві Російської академії наук. Наголошується на необхідності максимального освоєння рукописної спадщини історика та залучення їі до наукового обі2y.

Ключові слова: А.В. Флоровський, Катерина II, історіографія, Законодавча комісія 1767 р., рукописна спадщин, особовий архівний фонд

Одним із актуальних завдань сучасної історіографічної науки є звернення до проблеми виявлення несправедливо забутої чи втраченої наукової спадщини та її повторного запровадження до наукового обігу.

Документальне джерело, що відіграє головне значення в історичних дослідженнях, $€$ надзвичайно важливим і вагомим вже саме по собі, особливо з фактологічної точки зору. Запровадження до історіографічного контексту маловідомих або ж унікальних документів здатне привести до формування нових наукових напрямів, скорегувати сформовані уявлення про ті чи інші історичні події та осіб. У той же час архівне джерело стає доступним для більш широкої аудиторії. Саме тому пропонована стаття має на меті реконструкцію наукового доробку знаного історика та славіста Антонія Васильовича Флоровського (1884-1968) - професора Новоросійського та Карлового університету Праги, одного з найбільш відомих представників наукової еміграції першої чверті XX ст., котрий залишив після себе не тільки безліч опублікованих книг і статей, але й колосальну архівну спадщину, яка ще чекає своїх дослідників.

А.В. Флоровський народився в Україні 1 грудня 1884 р. у м. Єлисаветград Херсонської губернії. Освіту здобував в Одеській класичній гімназії (1894-1903) та на історико-філологічному факультеті Новоросійського університету (1903-1908). По закінченні навчання А.В. Флоровський був залишений при університеті для підготовки до професорського звання на кафедрі російської історії й отримав звання приватдоцента. Після захисту магістерської дисертації у Московському університеті в 1916 р. став професором кафедри російської історії Новоросійського університету. Одночасно читав курс лекцій з історії в інших навчальних закладах. Працював у наукових організаціях і товариствах - Одеському бібліографічному товаристві, Історико-філологічному товаристві (1912), Одеському товаристві історії та старожитностей (1911-1922). Був директором Одеської публічної бібліотеки (1921) та головної бібліотеки Одеської вищої школи (1922). 18 серпня 1922 р. А.В. Флоровський був заарештований і 25 серпня того ж року, після тижневого перебування у в’язниці НК ДПУ, був висланий з Одеси. Спочатку проживав у Софії, а пізніше постійно мешкав у Празі, де і закінчив свій нелегкий життєвий шлях. А.В. Флоровський значною мірою 
уособлював у 1920-ті - 1930-ті роки південноукраїнську історичну науку та трагічну долю цього покоління науковців.

А.В. Флоровський залишив по собі величезну наукову спадщину. Протягом усього свого життя він ретельно формував особистий архів, який після його смерті доля розділила на дві частини між Архівом АН СРСР (нині - Архів Російської академії наук) і Слов'янською бібліотекою у Празі (Slovanská knihovna v Praze). В обох частинах зібрання збереглася велика кількість рукописів історика, які ніколи не публікувалися, а також низка його статей, які пізніше були надруковані іноземними мовами ${ }^{1}$.

Систематичне вивчення особового фонду історика, що зберігається в Архіві РАН, почалося лише у 1990-і рр., але до сих пір він зберігає виняткові за своїм змістом рукописи про російську історію XVII-XIX ст., матеріали для вивчення Законодавчої комісії 1767-1768рр., еміграційних і депортаційних процесів у середовищі наукової еліти, історичного слов'янознавства, історіографії, історичної бібліографії.

У численному фонді А.В. Флоровського в Архіві РАН у Москві зберігся цікавий документ. Йдеться про невеликий за обсягом (28 аркушів) неопублікований нарис історика «Про Катерину II»². Попри те, що особовий фонд А.В. Флоровського був об'єктом спеціальних досліджень ${ }^{3}$, неодноразово слугував джерелом для написання наукових робіт як вітчизняних, так і російських вчених ${ }^{4}$ однак цей нарис до цього

\begin{abstract}
1 Див. детальніше: Лаптева Т.Н. Научное наследие А.В. Флоровского (1884-1968) в Архиве РАН // Вестник архивиста. 2014. № 1. С. 270-287; Лаптева Т.Н. Неизданные работы А.В. Флоровского: сохранность и отбор к публикации // Документ. Архив. Информационное общество: Сборник материалов III-ей Международной научно-практической конференции / Сост. Е.М.Бурова, О.Е. Антонова. Москва: $О 00$ «ТЕРМИКА.РУ», 2018. С. 469-475; Ковалев М.В. Личный фонд А.В. Флоровского в Славянской библиотеке в Праге: состав документов и история формирования // Фундаментальная наука: проблемы изучения, сохранения и реставрации документального наследия: Материалы Международной научной конференции / Отв. ред. В.Ю. Афиниани; Москва: Архив РАН, 2013. С. 137-138; Афиани В.Ю., Ковалев М.В., Лаптева Т.Н. К истории и перспективам изучения жизни и творчества Антония Васильевича Флоровского // Как зарождалась русская Прага: Материалы международного круглого стола, Прага, 26 июня 2017 г. / Редкол.: Е.И. Пивовар (отв. ред.), В.Ю. Афиани, Э. Ворачек, А.С. Левченков, Я. Немечек, И.Е. Ханова. Москва: РГГУ, 2017. С. 18-27; Мирончук А.С. Інформативні можливості Архіву Російської академії наук для реконструкції біографії і творчого доробку історика-славіста А.В. Флоровського // Слов'янознавство і нові парадигми та напрями соціогуманітарних досліджень: матеріали Міжнар. наук. конф. (Київ, 24 травня 2017 р.) / НАН України, Укр. ком. славістів, Нац. б-ка України ім. В.І. Вернадського, Ін-т укр. мови НАН України, Ін-т л-ри ім. Т.Г. Шевченка НАН України, Ін-т мистецтвознавства, фольклористики та етнології ім. М.Т. Рильського НАН України, Київ, нац. ун-т ім. Т. Шевченка. Київ,
\end{abstract} 2017. С. 304-309.

2 Архів Російської академії наук (Архів РАН). Ф. 1609. Оп. 1. Спр. 108.

3 Лаптева Т.Н. Личный фонд историка-эмигранта А.В. Флоровского в Архиве Российской академии наук: научное использование и реконструкция: автореф ... канд. ист. наук: 05.25.02. ФГБОУ ВО «Российский государственный гуманитарный университет». Москва, 2018. 25 с.

${ }_{4}^{4}$ Мирончук А. Нарис А.В.Флоровського з історії Законодавчої комісії 1767-1768 pp.: запровадження до історіографічного контексту // Історіографічні дослідження в Україні: збірник наукових праць. Київ: НАН України, Інститут історії України, 2017. Вип. 27. С. 360-382; Музичко О. Козакознавчі студії одеської школи істориків професора І.А. Линниченка // Чорноморська минувшина: Зб. наук. пр. 2009. Вип. 4. С. 143-156; Лаптева Т.Н. Малоизученный информационный ресурс для истории русского зарубежья - эпистолярное наследие А.В. Флоровского в Архиве РАН // Роль архивов в информационном обеспечении исторической науки: сборник статей / Авт.-сост. Е.А. Воронцова; отв. ред. В.Ю. Афиани, Ю.А. Петров. Москва: Этерна, 2017. С. 288-299; Лаптева Т.Н. Труды А.В. Флоровского по истории чешско-русских отношений, известные и неизвестные: рукописи ученого в Архиве РАН // Славянский мир в третьем тысячелетии. 2018. № 1-2. Вып. 13. С. 160-171; Аксенова Е.П. Институт им. Н.П. Кондакова: попытки реанимации (по материалам ар- 
часу не привертав уваги дослідників. Точний час написання статті невідомий. Архівістам також не вдалося з'ясувати час її появи, бо навіть на обкладинці архівної папки дата відсутня.

Наш дослідницький інтерес до рукопису, що аналізується, зумовлений передусім вивченням історії Законодавчої комісії зі створення нового Уложення 1767-1768 pр. Адже саме А.В. Флоровський започаткував справу академічного дослідження Комісії. Важливий внесок у формування її історіографічної традиції історик зробив передусім завдяки залученню величезної кількості неопублікованих архівних матеріалів із архівних сховищ Одеси, Москви, Петербурга та низки європейських архівів.

Нарис «Про Катерину II» написаний у жанрі історичного портрету. Цей жанр використовували багато відомих істориків. А.В. Флоровський також неодноразово звертався до написання історичних портретів відомих політичних діячів минулого. Єдиного методу написання таких робіт він не виробив, щоразу обираючи підхід, який би відповідав поставленому завданню. Окремі роботи історика мають на меті повідомити основні етапи життя особистості, охарактеризувати їі ставлення до явищ епохи та історичну роль. Наразі відомо більше десяти його опублікованих робіт, написаних у формі історичного портрета, а також 5 некрологів, що зберігаються у його особовому архівному фонді 5 .

В галереї А.В. Флоровського $€$ історичні нариси про діячів XVIII-XIX ст., підготовлені ним у 1920-х рр.: О.А. Безбородька6 ${ }^{6}$ О.Х. Бенкендорфа7, I.I. Бецького ${ }^{8}$

В особовому архіві історика збереглися конспекти лекцій, присвячених наступникам Петра I ${ }^{9}$, Олександру I та Миколі I10, Олександру II 11 , Олександру III ${ }^{12}$. Означені матеріали відносяться до 1933-1937 рр. Фактографічність викладу, а також і той факт, що більшість імен починаються на одну і ту ж літеру дозволяє припустити, що статті задумувалися як словникові або ж енциклопедичні. Не відкидаємо, що історик мав намір опублікувати їх у багатотомному довідково-енциклопедичному виданні «Творці історії» (Tvůrcové dĕjin).

А.В.Флоровському належить також нарис про чеського декабриста B.I. Враніцького, що був написаний у квітні 1928 р. й адресований чеським читачам 13 . Опублікований він був тільки через тридцять років - у 1958 р.14.

У середині 1930-х рр. А.В. Флоровський створив історичний портрет останнього

хива А.В. Флоровского) // Славяноведение. 1993. № 4. С. 63-74; Аксенова Е.П. Русские ученыеэмигранты первой волны в Югославии (по материалам архива А.В. Флоровского) // Русская эмиграция в Югославии: Сб. ст. Москва: Индрик, 1996. С. 148-166; Ковалев М.В., Лаптева Т.Н. «В Москве я был последний раз ровно 50 лет назад...». Из переписки Антония Васильевича Флоровского с советскими историками: В.Т. Пашуто, А.А. Зиминым и Е.П. Подъяпольской. 1957-1968 гг. // Исторический архив. 2014. № 4. С. 66-87.

5 Лаптева Т.Н. Научное наследие А.В. Флоровского (1884-1968) в Архиве РАН... С. 278.

6 Архів РАН. Ф. 1609. Оп. 1. Спр. 34.

7 Архів РАН. Ф. 1609. Оп. 1. Спр. 35.

8 Архів РАН. Ф. 1609. Оп. 1. Спр. 36.

${ }_{9}$ Архів РАН. Ф. 1609. Оп. 1. Спр. 123.

10 Архів РАН. Ф. 1609. Оп. 1. Спр. 124.

11 Архів РАН. Ф. 1609. Оп. 1. Спр. 122.

12 Архів РАН. Ф. 1609. Оп. 1. Спр. 125.

13 Архів РАН. Ф. 1609. Оп. 1. Спр. 20.

14 Florovskij A.V. V.I. Vranický, Čech-dekabrista // Kapitoly z dejin vzajemnych vztahu narodu CSR a SSSR. D.I. Praha, 1958. S. 39-67. 
російського імператора Миколи II ${ }^{15}$. Наявність серед списку джерел і літератури роботи, що була опублікована у 1934 р. дозволяє російській дослідниці О.П. Аксьоновій припустити, що нарис був написаний не раніше цього року16.

У 1930 р. в Ужгороді історик опублікував статтю про наставника імператора Петра II I.О.Зейкана'17.

Історичні портрети Івана Грозного 18 і патріарха Никона 19 А.В. Флоровський представив як доповіді на V міжнародному конгресі візантієвістів у Римі 22 вересня 1936 р. Робота про патріарха Никона була опублікована в 1935 р. у чеському довідково-енциклопедичному виданні «Творці історії»20.

У цьому ж виданні були опубліковані інші роботи А.В. Флоровського, виконані у жанрі історичного портрета, зокрема, про «підкорювача Сибіру» Єрмака Тимофійовича та М.В. Ломоносова 21.

Перейдемо безпосередньо до нарису «Про Катерину II». Він починається короткою біографічною довідкою, яка містить основні віхи життя російської імператриці. А.В. Флоровський розглядає її на фоні епохи, країни, документів, інших осіб, подій, явищ, різноманітних ідей і думок. Намагання Катерини II якомога краще познайомитись із новою країною сформувало у неї ідеал освіченого ліберального та гуманного монарха, історичне призначення якого полягало у перетворенні російської держави у відповідності з найкращими ідеями доби Просвітництва22. Однак, як зазначає автор, цей ідеал не знаходив повної відповідності у російській дійсності.

A.В. Флоровський відзначає заслуги Катерини II у здійсненні низки державних перетворень у внутрішньому житті Росії, а також вказує на досить «широку та багатозначну» програму зовнішньої політики, що призвела до значного збільшення території Росії та посилення її міжнародного становища 23.

Багато уваги історик приділяє законодавчим перетворенням російської імператриці. Ії̈ задум скликання Законодавчої комісії 1767 р., яка мала б створити проект нового Уложення замість застарілого кодексу законів 1649 р., він називає «блискучим» 24 .

Авторські оцінки щодо результатів і значення Уложеної комісії не відрізняються від наведених раніше у його спеціальних дослідженнях на цю тему. Попри те, що Комісія не завершила своєї роботи, однак її діяльність, на думку А.В.Флоровського, мала велике значення: з одного боку, накази від різних верств російського населення, представлені депутатами на розгляд Комісії, показали Катерині II та їі оточенню основні потреби і бажання населення Росії, з іншого - ті частини нового Уложення, які були вироблені у Комісії, послужили корисним матеріалами для подальших за-

\footnotetext{
15 Архів РАН. Ф. 1609. Оп. 1. Спр. 52.

16 Аксенова Е.П. Антоний Васильевич Флоровский о Романовых // Славяноведение. 2013. № 5. C. 69-70.

17 Флоровский А.В. Карпаторосс И.А. Зейкан - наставник императора Петра II (Несколько исторических справок) // Карпаторусский сборник. Ужгород, 1930. С. 112-122; окремий відбиток: Ужгород: Тип. «Шк. помощи», 1930. 11 с.

18 Архів РАН. Ф. 1609. ОП. 1. Спр. 54. Арк. 47-68.

19 Архів РАН. Ф. 1609. Оп. 1. Спр. 54. Арк. 69-98.

20 Florovskij A.V. Patriarch Nikon // Tvůrcové dĕjin. T. III. Praha, 1935. S. 369-375.

21 Florovskij A.V. Iermak // Tvůrcové dĕjin. T. III. Praha, 1935. S. 186-197; Florovskij A.V. Lomonosov // Tvůrcové dějin. T. III. Praha, 1935. S. 488-493.

22 Архів РАН. Ф. 1609. Оп. 1. Спр. 108. Арк. 3.

23 Архів РАН. Ф. 1609. Оп. 1. Спр. 108. Арк. 4.

24 Архів РАН. Ф. 1609. Оп. 1. Спр. 108. Арк. 6.
} 
конодавчих ініціатив самої Катерини II. Загалом же, вибори депутатів у Комісію і сама їі діяльність викликали пожвавлення суспільного руху по всій Росії, а також сприяли розвитку громадської думки в країні 25.

Щодо причин невдалої роботи Комісії 1767 р., яка остаточно була розпущена у 1774 р., А.В. Флоровський називає особисте невдоволення Катерини II, яку, ймовірно, не задовольнила громіздкість цієї установи та повільність їі роботи, що була спричинена організаційними недоліками. А головною причиною, напевно було те, що Катерина II стала усвідомлювати неможливість створення на абстрактних засадах європейської просвітницької думки Уложення для країни з багатонаціональним складом, з надзвичайно різноманітними умовами та нормами життя населення i, насамперед, за наявності кричущих протиріч у сфері соціальних та економічних відносин $^{26}$.

А.В. Флоровський не залишає осторонь питання про кріпосне право, яке піднімалось у ході роботи Уложеної комісії. Тут його оцінки досить однозначні: нічого важливого та значного не було зроблено з цього питання ${ }^{27}$. Це, на його думку, $є$ свідченням того, як з часом Катерина II відступала від заявлених у «Наказі» ідеалів і планів зробити російський народ найщасливішим на світі. Тому історик доходить висновку, що останні роки її царювання були різким контрастом у порівнянні з першими 28.

При уважному читанні рукопису складається враження, що А.В. Флоровський дає ніби не власні оцінки, а послуговується точкою зору самої імператриці: Катерина II залишила своїм наступникам Росію «органічно перетворену і вдосконалену у внутрішньому їі ладі та досить розвинену в громадському і культурному відношенні». Росія Катерини II була «істотно новою» і за своїм міжнародним становищем, і за своєю територією - підсумовує дослідник ${ }^{29}$.

«Досить багата і різноманітна» літературна спадщина Катерини II також $\epsilon$ предметом уваги А.В. Флоровського. Щоправда, законодавчі акти російської імператриці, як стверджує дослідник, значною мірою $є$ її особистою літературною роботою 30 .

До надзвичайно цінного літературного надбання імператриці А.В. Флоровський відносить ї̈ переписку з французькими філософами-просвітителями Вольтером і Д.Дідро, німецьким публіцистом епохи Просвітництва Ф.Гриммом, французьким скульптором Е.Фальконе. Драматичні ж твори Катерини II, на думку А.В. Флоровського, далекі від літературних ідеалів.

Історик схильний також вважати, що Катерині II належить авторство полемічної відповіді на скандальну книгу Ж.Ш.д’Отроша про Росію, що була анонімно видана під назвою «Антидот»31.

Загалом же, на переконання А.В. Флоровського, царювання Катерини II в історії Росії мало надзвичайно велике значення, а отже піднесений їй депутатами Законодавчої комісії 1767 р. титул «великої» $є$, на його думку, цілком законним і справедливим.

Можемо припустити, що нарис «Про Катерину II» був написаний у Празі. Таке

\footnotetext{
25 Архів РАН. Ф. 1609. Оп. 1. Спр. 108. Арк. 7-8.

26 Архів РАН. Ф. 1609. Оп. 1. Спр. 108. Арк. 8.

27 Архів РАН. Ф. 1609. Оп. 1. Спр. 108. Арк. 12.

28 Архів РАН. Ф. 1609. Оп. 1. Спр. 108. Арк. 13.

${ }^{29}$ Архів РАН. Ф. 1609. Оп. 1. Спр. 108. Арк. 16.

30 Архів РАН. Ф. 1609. Оп. 1. Спр. 108. Арк. 24.

31 Архів РАН. Ф. 1609. Оп. 1. Спр. 108. Арк. 27.
} 
припущення грунтується на тому, що в особовому фонді А.В.Флоровського в Архіві РАН $є$ ще один його рукопис - конспект курсу лекцій у Карловому університеті «Про історію Росії в період царювання Катерини II»32, який має безпосереднє відношення до аналізованого нами рукопису.

Серед відомих друкованих творів вченого ця лекція відсутня. Конспект являє собою автограф обсягом 151 аркуш, датований 1939-1940 рр. Ймовірно, що цей курс був розрахований на зимовий семестр 1939-1940 року. Очевидно також, що це незавершений рукопис, бо на останньому аркуші є запис: «Далее - о Комиссии из курса Ек[атерины] II. - С. 105-116». Отож, маємо всі підстави вважати, що А.В. Флоровський мав на увазі саме текст, який є предметом нашого дослідження.

Лекція носить радше популярний, аніж науковий характер. Даний автограф дає змогу розглянути питання зміни репрезентативної бази досліджень вченого у часі, а також погляди А.В. Флоровського на досліджувані події, зокрема на окремі аспекти російської історії часів правління Катерини II. Головні питання, над якими розмірковує А.В. Флоровський - організація верховної влади, проблема абсолютизму та самодержавства, співвідношення влади та закону в історії Росії XVIII ст., а також вплив ідей представників європейського Просвітництва на суспільно-політичну думку Росії другої половини XVIII ст.

Відзначимо, що А.В.Флоровський не вперше звертається до постаті російської імператриці Катерини II. Щоправда, перебуваючи за кордоном, він поступово відходив від катерининської тематики, звертався до неї лише епізодично, використовуючи вже напрацьований матеріал, і багато в чому повторюючи отримані раніше висновки. Втім, це не означає, що історія правління Катерини II не цікавила А.В. Флоровського зовсім. Вона знаходила своє відображення в університетських курсах з російської історії XVIII-XIX ст., які він став викладати у Карловому університеті замість 0.0. Кізеветтера після його смерті у березні 1933 р.33.

5 квітня 1932 р. А.В. Флоровський отримав ступінь доктора філософії Карлового університету, представивши в якості кваліфікаційної роботи свою одеську книгу «Склад Законодавчої комісії 1767-1774 рр.»34. Викладанню історії Росії на філософському факультеті Карлового університету А.В. Флоровський присвятив майже чверть століття. Однак, Карловий університет був не єдиним навчальним закладом, в якому історик вів викладацьку роботу.

Восени 1927 р. на базі Російського юридичного факультету у Празі М.В. Шахматов спільно з А.В.Флоровським утворили гурток любителів історії російського права. Попри те, що засідання цього гуртка носили камерний характер, під час них було зроблено кілька цікавих доповідей, зокрема А.В.Флоровського «Обряд управління Комісією 1767 р.»35.

У 1929 р. в Празі була опублікована стаття А.В. Флоровського «До характеристики імператриці Катерини II - законодавиці» ${ }^{36}$, яка продовжує цикл робіт про акти Катерини II, спрямовані до Законодавчої комісії зі створення проекту нового «Уложен-

\footnotetext{
32 Архів РАН. Ф. 1609. Оп. 1. Спр. 130.

33 Архів РАН. Ф. 1609. Оп. 1. Спр. 228. Арк. 12.

34 Архів РАН. Ф. 1609. Оп. 1. Спр. 228. Арк. 7.

35 Ковалев М.В. Русские историки-эмигранты в Праге (1920-1940-е годы). Саратов: Изд-во СГтУ, 2012. С. 197.

36 Флоровский А.В. К характеристике императрицы Екатерины II - законодательницы // Сборник Русского института в Праге. Т. 1. Прага, 1929. С. 261-278.
} 
ня» і присвячена вивченню тексту «Обряду управління Комісією 1767 р.». Рукопис цієї статті зберігається в особовому архіві історика в Архіві РАН ${ }^{37}$. Вчений аналізує безліч чорнових варіантів «Обряду», виділяє кілька його ранніх редакцій і порівнює варіанти вирішення питань організації Комісії на кожному з етапів ії діяльності, вплив різних осіб і факторів на остаточний варіант документа. Джерелами є відомі опубліковані тексти, які вчений піддає критичному аналізу.

Деякі ранні роботи вченого, що були вивезені ним під час депортації з Одеси, а також виписки та копії архівних матеріалів до досліджень про Уложену комісію 1767 р. зберігаються у його фонді у Слов'янській бібліотеці, серед яких: «Кілька доповнень з історії питання про справи церковні в Законодавчій комісії 1767 р.», «Комісія про дворянство. Башкири» й ін.38. Ймовірно, ці матеріали він використовував під час своєї викладацької діяльності.

Щоправда А.В. Флоровський, незважаючи на своє особливе місце у чеській історіографії, так і не створив власного підручника з історії Росії і, судячи з усього, навіть не вдавався до такої спроби.

Bci свої роботи А.В. Флоровський зазвичай спочатку писав від руки. Не $є$ винятком і нарис «Про Катерину II». Очевидно, що він готувався до публікації, оскільки на першому аркуші $\epsilon$ помітка історика, ймовірно для переписувача: «Прошу переписати у двох примірниках і перед відправкою дати мені текст переглянути».

За своєю формою аналізований нарис не зовсім не схожий на матеріали університетських лекцій, яких в архіві історика збереглося у великій кількості. Нарис не містить наукового апарату у вигляді бібліографічних посилань, приміток або списку використаних джерел. У тексті знаходимо лише посилання на зібрання творів Катерини II у 12 томах, видане Академією наук у 1901-1908 рр. за редакцією О.М. Пипіна та Я.Л. Барскова.

Це видається дещо дивним, оскільки, як справедливо зазначає російський дослідник М.В.Ковальов, А.В. Флоровський був вченим найвищої історіографічної культури, він завжди приділяв велику увагу наявній науковій літературі, стежив за роботами своїх колег ${ }^{39}$.

Заради справедливості відзначимо, що А.В. Флоровський не був майстром художнього слова, однак всі свої тексти він педантично вичитував і правив. Тут же редагування відсутнє. Читач також не відчує глибокого творчого натхнення. Замість нього - узагальнення вже відомого.

Історичне портретування, до якого вдається А.В. Флоровський - це метод особливого історичного жанру, який дає змогу зображати не лише особу, особистість, але й цілу епоху та сутність історичного явища. Для А.В. Флоровського не так важлива очевидна історична хроніка та логіка розвитку подій, скільки робота з перетворення очевидної реальності фактів у нову історичну реальність.

Аналізований нами нарис, можливо теж мав у своїй основі лекцію або, навпаки, повинен був послужити матеріалом для лекції, хоча він не містить навіть короткого плану-конспекту.

Створення історичного портрету Катерини II для А.В. Флоровського, з одного бо-

\footnotetext{
37 Архів РАН. Ф. 1609. Оп. 1. Спр. 32.

38 Slovanská knihovna v Praze. Trezor. A.V. Florovskij. T-FLOR. Krab. XLI.

39 Ковалев М.В. Неопубликованная статья А.В. Флоровского «Реформы, реакция, революция» из собрания Архива Российской академии наук // Архивный поиск: электронный сборник научных статей и публикаций. Вып. 1. Москва, 2019. C. 70. URL: http://arran.ru/files_/ar-poisk1.pdf
} 
ку, не така вже і важка справа, а з іншого - надзвичайно відповідальна з огляду на велику кількість вже існуючої спеціальної літератури, серед якої історик виділяє, у першу чергу, багатотомне фундаментальне дослідження майстра історичної біографії В.О. Більбасова «Історія Катерини ІІ» та яку називає найкращою біографією російської імператриці, а також вказує на детальний огляд іноземної літератури про Катерину II, вміщений у XII томі, що вийшов у Берліні в 1896 р.

При підготовці нарису А.В. Флоровський послуговувався також «Історією Катерини ІІ» О.Г. Брікнера, що з'явилася спочатку німецькою (1883р.), а пізніше російською (1885 р.) та італійською (1889 р.) мовами і містить солідну фактологічну базу. До речі, О.Г. Брікнер значну увагу, можливо надто надмірну, приділяє «Наказу» Катерини II та дещо переоцінює його значення. До певної міри оцінки А.В. Флоровського співзвучні з висновками О.Г. Брікнера. У короткому списку літератури, вміщеному наприкінці нарису, бачимо також капітальну працю С.М. Соловйова «Історія Росії з найдавніших часів».

Однією з важливих рис А.В. Флоровського є досить вміле оперування дослідницьким інструментарієм, а також використання різних теоретико-методологічних прийомів і підходів на основі їх доповнення. Досить часто він вдається до історикобіографічного методу історичного дослідження, спрямованого на опис, реконструкцію й аналіз обставин життя, результатів діяльності, психологічного портрета історичної особистості.

A.В. Флоровський у своєму нарисі прагне розкрити особистість Катерини II у всій повноті її життєвої історії, спираючись на результати ії діяльності. Однак, якщо говорити про залучення особливого корпусу джерел, які передбачає історикобіографічний метод - свідчень сучасників, щоденників, мемуарів, спогадів, то ми цього не побачимо. Теж саме можна сказати про застосування літературно-художніх прийомів викладу матеріалу (сюжетність, образність, емоційність) - вони також відсутні.

Оригінальні прижиттєві публікації праць А.В. Флоровського часто-густо недоступні через їх раритетність, оскільки виходили дуже скромними, якщо не сказати мізерними, накладами, переважно у зарубіжних наукових часописах, здебільшого не розміщених у вільному доступі в Інтернеті, і це певною мірою ускладнює доступ до них.

Цінність і важливість наукової спадщини А.В. Флоровського полягає у тому, що його праці були засновані на ширшому колі архівних джерел, як російських, так і європейських архівів, що у них він піднімав маловідомі сюжети з історії взаємин Росії та Східної і Центральної Європи, по-новому трактував багато питань російської істоpiï XVIII-XIX ст.

Без його наукових робіт сьогодні важко уявити вивчення законодавчих перетворень Російської імперії другої половини XVIII ст., адже саме він започаткував справу академічного дослідження Законодавчої комісії 1767-1768 pp. і зробив важливий внесок у справу формування ії̈ історіографічної традиції. Можемо прогнозувати дослідницький інтерес до рукописів А.В.Флоровського, в яких міститься інформація про Законодавчу комісію 1767 р. Всі ці обставини роблять надзвичайно важливою публікацію маловідомих і неопублікованих досліджень історика, що, у свою чергу, сприятиме запровадженню їх у широкий науковий обіг.

Максимальне освоєння документальної спадщини А.В. Флоровського та запровадження її до наукового обігу дозволить повною мірою реконструювати його науковий доробок і сприятиме поглибленню знань про розвиток історичної науки. 


\section{REFERENCES}

Aksenova, E.P. (2013). Antonii Vasilevich Florovskii o Romanovyh [Anthony Vasilyevich Florovsky about the Romanovs]. Slavianovedenie, 5, 69-77 [in Russian].

Aksenova, E.P. (1993). Institut im. N.P. Kondakova: popytki reanimacii (po materialam arkhiva A.V. Florovskogo) [The Institute named N.P. Kondakov: attempts of reanimation (by A.V. Florovsky archive)]. Slavianovedenie, 4, 63-74 [in Russian].

Aksenova, E.P. (1996). Russkie uchenye-emigranty pervoi volny v Yugoslavii (po materialam arkhiva A.V. Florovskogo) [Russian scientists-emigrants of the first wave in Yugoslavia (according to materials of the archive of A.V. Florovsky)]. In Russkaia emigratsiia $v$ Yugoslavii (pp. 148-166). Moskva: Indrik [in Russian].

Afiani, V.Yu., Kovalev, M.V. \& Lapteva, T.N. (2017). K istorii i perspektivam izucheniia zhyzni i tvorchestva Antoniia Vasilevicha Florovskogo [Towards the history and perspectives of studying the life and work of Anthony Vasilyevich Florovsky]. In Kak zarozhdalas russkaia Praga: Materialy mezhdunarodnogo kruglogo stola, Praga, 26 iiunia 2017 g. (pp. 18-27). Moskva: RGGU [in Russian].

Kovalev, M.V. (2013). Lichnyi fond A.V. Florovskogo v Slavianskoi biblioteke v Prage: sostav dokumentov i istoriia formirovaniia [A. Florovsky's personal fund in the Slavic Library in Prague: the composition of documents and the history of formation]. In Fundamentalnaia nauka: problemy izucheniia, sohraneniia $i$ restavratsii dokumentalnogo naslediia (pp. 131-138). Moskva: Arhiv RAN [in Russian].

Kovalev, M.V. (2019). Neopublikovannaia statia A.V. Florovskogo «Reformy, reakciia, revoliuciia» iz sobraniia Arkhiva Rossiiskoi akademii nauk [The unpublished article «Reforms, reaction, revolution» by A.V. Florovsky from the collection of the Archive of RAS] In Arkhivnyi poisk: elektronnyi sbornik nauchnyh statei i publikatsii, 1, 68-81. Retrieved from http://arran.ru/files_/ar-poisk1.pdf [in Russian].

Kovalev, M.V. (2012). Russkie istoriki-emigranty v Prage (1920-1940-e gody) [Russian historiansemigrants in Prague (1920-1940s)]. Saratov [in Russian].

Kovalev, M.V. \& Lapteva, T.N. (2014). «V Moskve ya byl poslednii raz rovno 50 let nazad...». Iz perepiski Antoniia Vasilevicha Florovskogo s sovetskimi istorikami: V.T. Pashuto, A.A. Ziminym i E.P. Podiapolskoi. 1957-1968 gg. [«In Moscow, I was the last time exactly 50 years ago...». From the correspondence of Anthony Vasilyevich Florovsky with Soviet historians: V.T. Pashuto, A.A. Zimin, and E.P. Podyapolskaya. 1957-1968]. Istoricheskii arkhiv, 4, 66-87 [in Russian].

Lapteva, T.N. (2018). Lichnyi fond istorika-emigranta A.V. Florovskogo v Arhive Rossiiskoi akademii nauk: nauchnoe ispolzovanie i rekonstrukciia [The personal fund of the emigrant historian A.V. Florovsky in the Archives of the Russian Academy of Sciences: scientific use and reconstruction]. (Extended abstract of Candidate's thesis). Moskva. [in Russian].

Lapteva, T.N. (2017). Maloizuchennyi informatsionnyi resurs dlia istorii russkogo zarubezhia epistoliarnoe nasledie A.V. Florovskogo v Arhive RAN [Byway information resource for the history of the Russian diaspora - the epistolary heritage of A.V. Florovsky in the Archive of the RAS] In Rol arkhivov v informatsionnom obespechenii istoricheskoi nauki: sbornik statei (pp. 288-299). Moskva: Eterna [in Russian].

Lapteva, T.N. (2014). Nauchnoe nasledie A.V. Florovskogo (1884-1968) v Arkhive RAN [Scientific heritage of A.V. Florovsky (1884-1968) in the RAS Archive]. Vestnik arkhivista, 1, 270-287 [in Russian].

Lapteva, T.N. (2018). Neizdannye raboty A.V. Florovskogo: sohrannost i otbor k publikacii [Unpublished works of A.V. Florovsky: safety and selection for publication]. In Dokument. Arkhiv. Informatsionnoe obshhestvo: Sbornik materialov III-ei Mezhdunarodnoi nauchno-prakticheskoi konferencii (pp. 469475). Moskva: 000 «TERMIKA.RU» [in Russian].

Lapteva, T.N. (2018). Trudy A.V. Florovskogo po istorii cheshsko-russkih otnoshenii, izvestnye i neizvestnye: rukopisi uchenogo v Arkhive RAN [Known and unknown Antoniy Florovsky's works on the history of Czech-Russian relations: manuscripts of the scientist in the Archive of the Russian Academy of Sciences] In Slavianskii mir v tretem tysiacheletii, 1-2 (13), 160-171 [in Russian].

Myronchuk, A. (2017). Narys A.V. Florovskoho z istorii Zakonodavchoi komisii 1767-1768 rr.: zaprovadzhennia do istoriohrafichnoho kontekstu [The essay of A.V. Florovsky from the history of the Legislative Commission of 1767-1768: introduction to the historiographical context]. Istoriohrafichni doslidzhennia v Ukraini, 27, 360-382 [in Ukrainian].

Myronchuk, A.S. (2017). Informatyvni mozhlyvosti Arkhivu Rosiiskoi akademii nauk dlia rekonstruktsii biohrafii i tvorchoho dorobku istoryka-slavista A.V. Florovskoho [Informational opportunities of Archive of the Russian Academy of Sciences for the reconstruction of the biography and scientific heritage of the historian and Slavist A.V. Florovsky]. In Slovianoznavstvo i novi paradyhmy ta napriamy sotsiohumanitarnykh doslidzhen: materialy Mizhnarodnoi naukovoi konferentsii (Kyiv, 24 travnia 2017 r.) (pp. 304-309). Kyiv [in Ukrainian]. 
Muzychko, 0. (2009). Kozakoznavchi studii Odeskoi shkoly istorykiv profesora I.A. Lynnychenka [Cossack studies of Odesa historical school of professor I.A. Lynnychenko]. Chornomorska mynuvshyna, 4, 143-156 [in Ukrainian].

Florovskij, A.V. (1935). Iermak [Iermak]. In Tvůrcové dějin (T. III, pp. 186-197). Praha [in Czech].

Florovskij, A.V. (1935). Lomonosov [Lomonosov]. In Tvưrcové dějin (T. III, pp. 488-493). Praha [in Czech].

Florovskij, A.V. (1935). Patriarch Nikon [Patriarch Nikon]. In Tvưrcové dějin (T. III, pp. 369-375). Praha [in Czech].

Florovskij, A.V. (1958). V.I. Vranický, Čech-dekabrista [Cech Decembrist V.I. Wranitzky]. In Kapitoly z dejin vzajemnych vztahu narodu CSR a SSSR (pp. 39-67). Praha [in Czech].

Florovskii, A.V. (1929). K harakteristike imperatritsy Ekateriny II - zakonodatelnitsy [To the characteristic of empress Ekaterina II - legislator]. In Sbornik Russkogo instituta v Prage, 1, 261-278 [in Russian].

Florovskii, A.V. (1930). Karpatoross I.A. Zeikan - nastavnik imperatora Petra II (Neskolko istoricheskikh spravok) [Karpatoross, I.A. Zeykan - tutor to Emperor Peter II (Several historical references)] In Karpatorusskii sbornik (pp. 112-122). Uzhhorod [in Russian].

\section{Anatolii Myronchuk}

(Vernadsky National Library of Ukraine, Kyiv, Ukraine)

ORCID: https://orcid.org/0000-0001-5633-1413

\section{Unpublished essay «About Catherine II» by A.V. Florovskyi: reconstruction of the scientific heritage}

An unpublished essay «About Catherine II» by A.V. Florovskyi from his personal fund in the Archive of the Russian Academy of Sciences is analyzed in the paper, and also the need for maximum study of the historian's handwritten heritage and its introducing into scientific circulation is emphasized.

One of the relevant goals of modern historiographical science is the appeal to the problem of revealing the unjustly forgotten or lost scientific heritage and its re-introduction into scientific circulation. Despite the fact that the personal fund of the historian and Slavist A.V. Florovskyi was repeatedly the subject of thorough study, the analyzed essay has not so far attracted the attention of the scholars.

The essay «About Catherine II» was written in the genre of a historical portrait. The exact time of writing is unknown. A.V. Florovskyi considers Catherine II in the context of an epoch, empire, documents, other people, events, phenomena, various ideas, and thoughts. He describes the personality of the Russian Empress in the entire completeness of her life story, taking into account the results of her activities.

A.V. Florovskyi notes the merits of Catherine II in implementing a series of transformations in Russia's home and foreign policy. Much attention the historian pays to the legal reforms of the Russian Empress. The author's estimates of the Legislative Commission of 1767 results and significance do not differ from the ones previously mentioned in his special studies of the issue. The Subject of A.V. Florovskyi's attention is also the literary heritage of Catherine II.

It is assumed that the studied essay was written in Prague. The research interest in A.V. Florovskyi's manuscripts, containing the information on the Legislative Commission of 1767 is predicted. The necessity of publishing the little-known and unpublished works of the historian, which will facilitate their introduction into a wide scientific circle, is noted.

Maximal study of A.V. Florovskyi's documentary heritage and introducing it into scientific circulation will allow to fully reconstruct his scientific achievements and contribute to the deepening of knowledge about the development of historical science.

Keywords: A.V. Florovskyi, Catherine II, historiography, Legislative Commission of 1767, handwritten heritage, personal archive fund 